\title{
PENGARUH MODERASI VISI STRATEGIK TERHADAP HUBUNGAN KETERLIBATAN STRATEGIK DENGAN PERSEPSI KETIDAKPASTIAN LINGKUNGAN, PERSEPSI KEKUATAN KOMPETITIF, KETERLIBATAN KERJA, DAN KOMITMEN ORGANISASIONAL (SUATU RENCANA STUDI PADA SMU DAN SMK SEKECAMATAN CILEUNGSI KABUPATEN BOGOR)
}

\author{
Agus Fauzi \\ Universitas Satya Negara Indonesia \\ agusfauzi526@yahoo.co.id
}

\begin{tabular}{lll}
\hline Received : & Accepted : & Published: \\
1 Januari 2022 & 15 Februari 2022 & 25 Februari 2022 \\
\hline
\end{tabular}

\begin{abstract}
ABSTRAK
Penelitian ini bertujuan untuk menghasilkan model penelitian yang memoderasi dampak visi strategis terhadap hubungan keterlibatan strategis dengan persepsi ketidakpastian lingkungan, persepsi kekuatan kompetitif, keterlibatan kerja, dan komitmen organisasi. Penelitian ini merupakan tinjauan pustaka, sehingga metode yang digunakan adalah tinjauan pustaka. Penelitian ini dilakukan dengan mempelajari teori-teori yang telah ditetapkan. Penelitian ini juga bersumber dan berdasarkan hasil penelitian sebelumnya, khususnya hasil penelitian empiris yang berkaitan dengan variabel-variabel yang diteliti dalam artikel ini. Selain itu, jika dilanjutkan dalam penelitian empiris, populasi penelitian ini adalah Kepala Sekolah dan Wakil Kepala SMA dan SMK di Kecamatan Cileungsi Kabupaten Bogor. Penelitian ini menghasilkan model penelitian yang menjelaskan pengaruh moderasi visi strategis terhadap hubungan keterlibatan strategis dengan persepsi ketidakpastian lingkungan, persepsi kekuatan kompetitif, keterlibatan kerja, dan komitmen organisasi. Hipotesis meliputi pengaruh moderasi visi strategis terhadap hubungan keterlibatan strategis berhubungan positif dan signifikan terhadap persepsi ketidakpastian lingkungan, persepsi kekuatan kompetitif, keterlibatan kerja, dan komitmen organisasi. Visi strategis memoderasi hubungan keterlibatan strategis dengan persepsi ketidakpastian lingkungan, Visi strategis memoderasi hubungan keterlibatan strategis dengan persepsi kekuatan kompetitif, keterlibatan kerja, dan komitmen organisasi.
\end{abstract}

Kata Kunci : Visi Strategis, Keterlibatan Strategis, Persepsi Ketidakpastian Lingkungan, Persepsi Kekuatan Kompetitif, Keterlibatan Kerja, Komitmen Organisasi

\begin{abstract}
The study in this article aims to produce a model of research moderating impact of strategic vision to the relationship of strategic involvement with perception of environment uncertainty, perception of competitive strength, job involvement, and organizational commitment. This article is a review of the literature, so that method being used is a literature review. This study is conducted by studying theories that have been established. The study also sourced and based on the results of previous research, especially empirical research results related to the variables that were studied in this article. In addition, if it is continued in empirical research, the study population are Head Master and Vice Head Master of SMU and SMK in Kecamatan Cileungsi Kabupaten Bogor. This article study produces a research model that explains the moderating impact of strategic vision to the relationship of strategic involvement with perception of environment uncertainty, perception of competitive strength, job involvement, and organizational commitment. Hypotheses include the following;
\end{abstract}


moderating impact of strategic vision to relationship strategic involvement is positively related and significant to perception of environment uncertainty, perception of competitive strength, job involvement, and organizational commitment. Strategic vision moderate the relationship of strategic involvement with perception of environment uncertainty, Strategic vision moderates the relationship of strategic involvement with perception of competitive strength, job involvement, and organizational commitment.

Keywords: Strategic Vision, Strategic Involvement, Perception of Environment Uncertainty, Perception of Competitive Strength, Job Involvement, Organizational Commitment

\section{PENDAHULUAN}

Untuk mencapai kepemimpinan strategik membutuhkan konsep bisnis yang visioner (Thompson \& Strickland, 2003). Visi merupakan arah nyata dan memetakan jalur strategik. Sejumlah penelitian yang menguji visi telah memperoleh hasil bahwa, visi dapat mempengaruhi perilaku dan sikap kerja manajer yang lebih baik (Larwood, Falbe, Kringer, \& Miesing, 1995). Larwood et al., (1995), menemukan bahwa manajer yang mengkomunikasikan visi dengan baik, diketahui anggota, mudah dipahami, dan dinyatakan dengan jelas lebih responsif terhadap perubahan eksternal.

Keely (2000), menemukan bahwa, visi organisasi yang diketahui dan mudah dipahami oleh anggota akan mengefektifkan proses komunikasi antara manajer dan karyawan. Thus, visi yang dikomunikasikan dengan baik, diketahui anggota organisasi, mudah dipahami, dan dinyatakan dengan jelas disebut visi strategik (Conger, 1989; Nanus, 1992; Oswald, Mossholder, \& Harris, 1997; Thompson \& Strikcland, 2003). Dalam mempengaruhi perilaku manajer, visi berinteraksi dengan keterlibatan strategic manajer (Oswald et al., 1994; 1997). Sedang, keterlibatan strategik berpengaruh langsung terhadap persepsi ketidakpastian lingkungan dan kekuatan kompetitif organisasi (Oswald et al., 1994; 1997).

Sementara, Wooldridge dan Floyd (1990) menemukan keterlibatan manajer dalam memformulasikan strategi mempertinggi komitmen mereka. Manajer berkomitmen terhadap organisasi jika masukannya terakomodasi dalam membuat keputusan (Oswald et al., 1994). Intensitas dalam memformulasikan strategi memicu manajer lebih konsentrasi pada pekerjaan dan mewujudkan komitmen. Keterlibatan dalam formulasi strategi mempertinggi komitmen manajer untuk strategi (Wooldrige \& Floyd, 1990). Kesempatan terlibat dalam formulasi strategi juga meningkatkan keterlibatan kerja dan komitmen organisasional (Oswald et al., 1994).

Dengan demikian, visi strategik memoderasi hubungan keterlibatan strategik dengan persepsi ketidakpastian lingkungan, persepsi kekuatan kompetitif, keterlibatan kerja, dan komitmen organisasional. Isu ini menarik di Indonesia akhir-akhir ini, yang mana banyak pperguruan tinggi melakukan transformasi strategik dan perubahan karena pertumbuhan domestik dan persaingan global. Oleh karena itu, penelitian ini bertujuan menguji hubungan keterlibatan strategik dengan persepsi ketidakpastian lingkungan, persepsi kekuatan kompetitif, keterlibatan kerja, dan komitmen organisasional, serta menguji pengaruh pemoderasian visi strategik terhadap hubungan variabelvariabel tersebut.

\section{KAJIAN TEORI}

\section{Visi Strategik}

Visi Strategik adalah keyakinan yang kuat tentang masa depan organisasi, yang mudah dipahami dan diterjemahkan, serta apa yang sebaiknya dilakukan organisasi terhadapnya (Thompson \& Strickland, 2003). Menurut Nanus (1992), visi strategik adalah pandangan masa depan organisasi yang 
dinyatakan dengan jelas dan mudah dipahami.

\section{Keterlibatan Strategik}

Keterlibatan strategik adalah intensitas manajer dalam menyusun strategi organisasi (Oswald et al., 1997). Keterlibatan strategik lebih ditentukan oleh seberapa nten ikut menyusun strategi. Keterlibatan strategik menjadi sarana mempersepsikan lingkungan eksternal, kekuatan kompetitif, keterlibatan kerja dan menentukan komitmen organisasional (Oswald et al., 1994; 1997). Makin inten keterlibatan strategik manajer, makin tinggi memperoleh informasi untuk menyusun strategi (Parnell, Lester, \& Menefee, 2000).

\section{Persepsi Ketidakpastian Lingkungan}

Persepsi ketidakpastian lingkungan adalah persepsi manajer terhadap faktor eksternal seperti kondisi ekonomi, perkembangan teknologi, lingkungan industri, pelanggan, dan pesaingnya (Parnell et al., 2000; Gordon \& Narayanan, 1984). Pengukuran persepsi ketidakpastian lingkungan dengan dua atribut, yakni kedinamisan dan kompleksitas lingkungan eksternal yang berinteraksi dengan organisasi (Bourgeois, 1985). Dalam penelitian ini, lingkungan ekonomi dan teknologi digunakan istilah stabil-turbulen, untuk lingkungan pesaing dan persaingan digunakan istilah mengancam-tidak mengancam, untuk perubahan konsumen digunakan istilah dinamis-statis (Oswald et al., 1994; Oswald et al., 1997).

\section{Persepsi Kekuatan Kompetitif}

Persepsi kekuatan kompetitif adalah persepsi manajer dalam membandingkan kompetensi organisasi dengan indikator kunci kesuksesan industri (Sceneider \& de Meyer, 1991). Untuk mengetahui kekuatan kompetitif dengan menilai faktor-faktor sukses kunci industri (Oswald et al., 1997). Dalam mempersepsikan kekuatan kompetitif adalah dengan membandingkan organisasi dengan pesaing paling kuat, dengan dimensi seperti arah strategik, keefektifan pemasaran, keahlian manajerial, citra public, dan kepemimpinan (Oswald et al., 1997).

\section{Keterlibatan Kerja}

Kanungo (1992) mengartikan keterlibatan kerja sebagai perasaan seseorang bahwa dirinya menjadi bagian tidak terpisah dari pekerjaan. Dubin (1985), memberi pengertian keterlibatan kerja sebagai seberapa tinggi pekerjaan dipersepsikan menjadi sumber kepuasan memenuhi kebutuhan. Manajer melibatkan dalam pekerjaan jika pekerjaan tersebut punya pengaruh terhadap harga dirinya (Huselid \& Day, 1991).

\section{Komitmen Organisasional}

Komitmen organisasional adalah keinginan untuk bertahan dalam organisasi, berusaha lebih maksimal demi organisasi, serta bersedia menerima nilai-nilai dan tujuan organisasi (Luthan, 1995). Keterlibatan manajer dalam merumuskan strategi mempertinggi komitmen organisasi. Individu lebih berkomitmen jika masukannya mempengaruhi keputusan organisasi. Keputusan strategik menjadi bagian penting organisasi dan keterlibatan manajer menyusun strategi mempertinggi komitmen mereka terhadap organisasi (Oswald et al., 1994).

\section{METODE PENELITIAN}

Dalam rencana penilitian ini, metode yang digunakan adalah tinjauan pustaka. Rencana penelitian ini dilakukan dengan mempelajari teori-teori yang telah ditetapkan. Rencana penelitian ini juga 
bersumber dan berdasarkan hasil penelitian sebelumnya, khususnya hasil penelitian empiris yang berkaitan dengan variabel-variabel yang diteliti dalam artikel ini. Selain itu, jika dilanjutkan dalam penelitian empiris, populasi dalam rencana penelitian ini adalah Kepala Sekolah dan Wakil Kepala Sekolah SMU dan SMK di Kecamatan Cileungsi Kabupaten Bogor.

\section{Rencana Metodologi dan Hasil Pembahasan}

Pada bagian ini membahas rencana metodologi yang akan digunakan dalam penelitian ini serta kerangka berpikir atas keterkaitan antar variable-variabel sebagai hasil kajian pembahasan dalam rencana penelitian ini.

\section{Desain, Populasi dan Sampel}

Rencana penelitian ini menggunakan metode survei dengan instrument berupa kuesioner. Populasi penelitian ini adalah pejabat Sekolah Menengah Umum (SMU) dan Sekolah Menengah Kejuruan (SMK) sekecamatan Cileungsi, dengan sebutan Kepala Sekolah dan Wakil Kepala Sekolah, dengan level of analysis individual. Sedangkan jumlah sampel yang dakan dikumpulkam menggunakan purposive sampling atau lebih spsifik judgment sampling, yang memenuhi kriteria. Pertama, responden adalah Kepala Sekolah dan Wakil Kepala Sekolah SMU dan SMK. Kedua, responden telah bekerja di sekolah tersebut minimal 1 tahun (Oswald et al., 1997). Ketiga, respoden menduduki jabatan sekarang minimal 1 bulan (Oswald et al., 1997).

\section{Pengukuran Variabel \\ Visi Strategik}

Visi strategik adalah keyakinan yang kuat tentang masa depan organisasi dan suatu tindakan apa yang harus dilakukan organisasi untuk itu, melalui pernyataan yang jelas, mudah dipahami, disepakati bersama, dan cocok bagi organisasi. Dalam pengukuran ini diajukan tiga pertanyaan. Rentang pilihan dari 1 (sedikit sekali) sampai 5 (besar sekali).

\section{Keterlibatan Strategik}

Keterlibatan strategik adalah intensitas manajer memformulasikan strategi organisasi. Ada empat pertanyaan, dua pertanyaan mengukur sejauh mana manajer terlibat dalam perencanaan strategik organisasi dan unit kerjanya. Rentang pilihan dari 1 (sangat sedikit terlibat) sampai dengan 5 (sangat terlibat). Sedang, dua pertanyaan untuk mengukur sejauh mana pekerjaan mensyaratkan manajer memikirkan masa depan dan perencanaan unit kerjanya. Rentang pilihan dari 1 (sangat tidak setuju) sampai dengan 5 (sangat setuju).

\section{Persepsi Ketidakpastian Lingkungan}

Persepsi ketidakpastian lingkungan adalah persepsi manajer terhadap faktor eksternal seperti lingkungan industri, ekonomi, pelanggan, pesaing, dan lain-lain. Pengukuran ini menggunakan instrumen hasil modifikasi Gordon dan Narayanan (1987), terdiri dari 7 butir pertanyaan.

\section{Persepsi Kekuatan Kompetitif}

Persepsi ketidakpastian lingkungan adalah persepsi manajer membandingkan kompetensi organisasi dengan indikator kunci kesuksesan industri. Manajer ditanya untuk membandingkan dengan pesaing yang paling kuat, dengan berbagai dimensi dengan rentang pilihan 1 (sangat lebih buruk) sampai 5 (sangat lebih baik).

\section{Keterlibatan Kerja}

Keterlibatan kerja adalah perasaan manajer secara pribadi bahwa dirinya menjadi bagian tidak terpisahkan dari pekerjaannya. Pengukuran variabel ini menggunakan 5 item job involvement questionaire yang dikembangkan Kanungo (1992), dengan rentang pilihan dari 1 (sangat tidak setuju) 
sampai 5 (sangat setuju).

\section{Komitmen Organisasional}

Komitmen organisasional adalah keinginan mempertahankan keanggotaan organisasi, kemauan berusaha untuk organisasi, dan keyakinan menerima nilai dan tujuan organisasi. Variabel ini diukur dengan organizational commitment questionnaire (Mowday, Steers, dan Porter, 1979). Dari 15 skala item asli, hanya 9 versi pendek yang digunakan. Rentang pilihan 1 (sangat tidak setuju) sampai 5 (sangat setuju).

\section{Variabel kontrol}

Variabel kontrol dalam penelitian ini adalah jenis kelamin, masa jabatan, level manajemen, yang diduga ikut mempengaruhi variabel dependen.

\section{Analisis Data}

Alat analisis yang akan digunakan adalah Moderated Regression Analysis (MRA). Ada empat macam model yang digunakan dalam penelitian ini yakni model 1, 2, 3, 4, dan tiga langkah dalam pengujian untuk masing-masing model. Langkah pertama, memasukkan control variable ke setiap model. Langkah kedua, skor total independent variable terhadap dependent variable. Langkah ketiga, interaksi moderator variable dan independent variable ke setiap model.

\section{HASIL PEMBAHASAN}

\section{Keterlibatan Strategik dan Ketidakpastian Lingkungan}

Analisis lingkungan dilakukan ketika manajer memformulasikan strategi. Meningkatnya kompleksitas lingkungan mengakibatkan manajer makin tidak pasti dalam memperspsikan lingkungan. Manajer secara intensif memahami ketidakpastian lingkungan jika memperoleh keterlibatan tinggi dalam merumuskan strategi (Oswald et al., 1997). Makin tinggi kesempatan maka semakin banyak mempersepsikan ketidakpastian lingkungan. Manajer yang semakin terlibat memformulasikan strategi semakin banyak mempersepsikan ketidakpastian lingkungan (Oswald et al., 1997).

H1: Keterlibatan strategik berhubungan positif dan signifikan dengan persepsi ketidakpastian lingkungan.

\section{Keterlibatan Strategik dan Persepsi Kekuatan Kompetitif}

Keterlibatan strategik memfokuskan persepsi kekuatan kompetitif (Oswald et al., 1997). Keakuratan analisis industri memudahkan dalam mengenali pesaing dan mengevaluasi kekuatan dan kelemahan organisasi untuk menghadapinya (Porter, 1980). Manajer menganalisis kekuatan kompetitif secara maksimal jika mempunyai kesempatan yang memadai. Kesempatan tersebut diperoleh jika manajer terlibat maksimal dalam memformulasikan strategi.

H2: Keterlibatan strategik berhubungan positif dengan persepsi kekuatan kompetitif.

\section{Keterlibatan Strategik dan Keterlibatan Kerja}

Oswald et al. (1994) menemukan, keterlibatan kerja manajer dipengaruhi keterlibatannya dalam merumuskan strategi. Keterlibatan strategik menumbuhkan perasaan tidak terpisahkan dari pekerjaannya (Oswald et al., 1994). Sehingga keterlibatan dalam pengambilan keputusan mempengaruhi keterlibatan kerja.

H3: Keterlibatan strategik berhubungan positif dengan keterlibatan kerja. 


\section{Keterlibatan Strategik dan Komitmen Organisasional}

Wooldridge dan Floyd (1990) menyatakan, keterlibatan manajer mempertinggi komitmen mereka. Kim dan Mauborgne (1993) menemukan, implikasi positif komunikasi dalam pekerjaan termasuk dalam memformulasikan strategi adalah komitmen organisasional. Semakin tinggi keterlibatan strategic makin meningkatkan komitmen organisasi (Oswald et al., 1994).

H4: Keterlibatan strategik berhubungan positif dengan komitmen organisasional.

\section{Visi Strategik Memoderasi Hubungan Keterlibatan Strategik dengan Persepsi Ketidakpastian Lingkungan, Persepsi Kekuatan Kompetitif, Keterlibatan Kerja, dan Komitmen Organisasional}

Keely (2000) menemukan, komunikasi lebih efektif karena visi yang diterima dan dimengerti anggota. Komunikasi dimaksud adalah komunikasi pekerjaan termasuk dalam memformulasi strategi. Larwood et al. (1995) menemukan, manajer yang mengkomunikasikan visi dengan baik, diketahui anggota, jelas dan mudah dipahami lebih responsif terhadap perubahan eksternal. Oswald et al., (1997) menyatakan, visi yang menjadi pedoman perencanaan strategic mendorong manajer lebih terlibat dalam formulasi strategi dan memperngaruhi perilaku kerjanya.

H5: Visi strategik memoderasi hubungan keterlibatan strategik dengan persepsi ketidakpastian lingkungan.

H6: Visi strategik memoderasi hubungan keterlibatan strategik dengan persepsi kekuatan kompetitif.

H7: Visi strategik memoderasi hubungan keterlibatan strategik dengan keterlibatan kerja.

H8: Visi strategik memoderasi hubungan keterlibatan strategik dengan komitmen organisasional.

\section{KESIMPULAN}

Dari kajian keterkaitan antar variable yang menghasilkan beberapa hipotesis, maka dalam tulisan artikel ini dapat disimpulkan dan dibangun model penelitian seperti pada gambar berikut ini. 


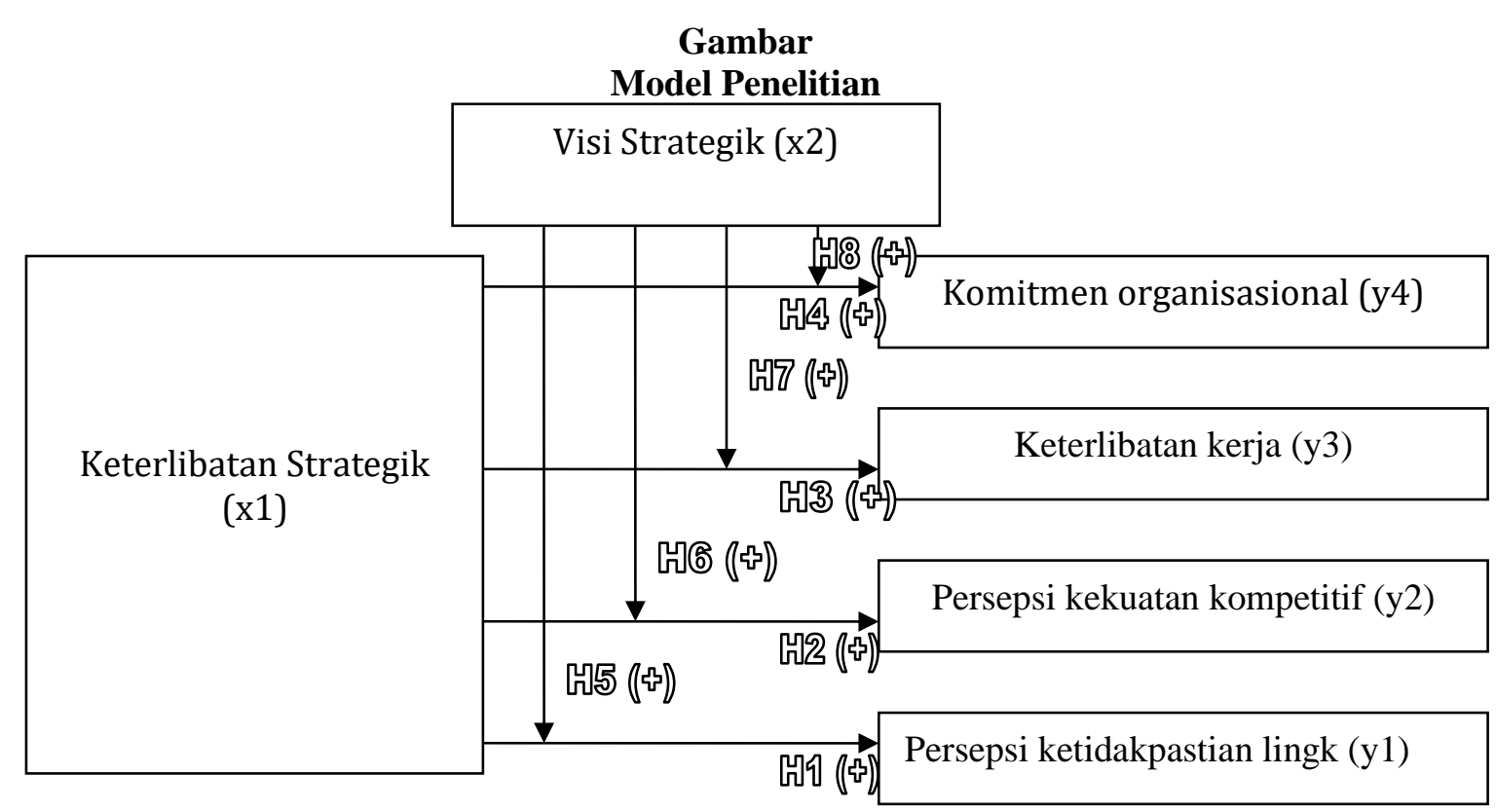

\section{DAFTAR PUSTAKA}

Bourgoeouis, 11l, L.J. 1985. Strategic goal, perceived uncertainty, and economic performance in volatile environment. Academy of Management Journal, 28 (3): 548-573.

(Conger, J.A. 1989. The Charismatic Leader: Beyond The Mystique of Exceptional Leadership, San Fransisco: Jossey-Bass.

Dubin, R. 1956. Industrial worker's world: a study of central life interests of industrial workers, Social Problem, dalam Blau,G.J. 1985. A multiple study investigation of the dimensionality of job involvement. Journal of Vicational Behavior, 9: 19-36.

Gordon.L.A \& Narayanan, V.K. 1984. Management accounting systems, perceived environment uncertainty, and organizational structure: an empirical investigation. Accounting Organization \& Social, 9 (1): 33-47.

Hair, J.F. Jr., R.E. Anderson, R.L.Atham, \& W.C. Black 1998. Multivariate data Analysis, New Jersey: Prentice hall,Inc.

Huselid,M.A \& Day,N.E. 1991. Organizational commitment, job involvement, and turnover: a substantive and methodological analysis. Journal of Applied Psychology, 76: 380-391.

Ireland,R.D., Hitt, M.A., \& de Porras, D.A. 1987. Strategy formulation process differences in perception of strength and weaknesses indicators and environmental uncertainty by managerial level. Strategic Management Journal, 8: 459-485.

Kanungo,R.N. 1982. Measurement of job and work involvement. Journal of Applied Psychology, 67: 341-349.

Kelly,D. 2000. Using vision to improve organizational communication. Leadership \& Organization Development Journal, 21 (2): 92-101.

Larwood,L., Falbe, C.M., Kringer, M.P, \& Miesing, P. 1995. Structure and meaning of organizational vision. Academy of Management Journal, 38 (3): 740-769. 
Nanus,B. 1992. Visionary Leadership: Creating A Compelling Sense of Direction For Your Organization. san Fransisco: Jossey-Bass.

Oswald,S.L., Mossholder, K.W. \& Harris, S.G. 1994. Vision salience and strategic involvement: implication for psychological attachment to organizational and job. Strategic management Journal, 15: 477-489.

Oswald,S.L., Mossholder, K.W. \& Harris, S.G. 1997. Relations between strategic involvement and manager's perception's of environment and competitive strengths. Group \& Organization management, 22 (3): 343-365.

Parnell, J.A., Lester, D.L., \& Menefee M.L. 2000. Strategy as response to organizational uncertainty: an alternative perspective on the strategy-performance relationship. Management Decision, 38 (8): 520-530.

Porter, M. 1980. Competitive Strategy: Techniques For Analyzing Industries and Competitor, New York: Free Press.

Sekaran,U. 2003. Research Methods For Business, 4 ed, New York; John Wiley \& Sons, Inc.

Strickland,A.J. \& Thompson,A.A. 2003. Strategic Management: Concept and Cases, New Jersey: Prentice Hall Int.Inc.

Sutcliffe, A.M. 1994. What executive notice: accurate perception in top management team. Academy of Management Journal, 37 (5): 1360-1378.

Wang, P. \& Chan, P.S. 1995. Top management perception of strategic processing in a turbulent environment. Leadership \& Organization Development Journal. 16 (7): 33-43.

Wooldridge, B. \& Floyd, S.W. 1990. The strategy process, middle management involvement, and organizational performance. Strategic Management Journal. 11: 231-241. 